\title{
Toxicological Evaluation and Protective Effects of Ethanolic Leaf Extract of Cassia spectabilis DC on Liver and Kidney Function of Plasmodium berghei-Infected Mice
}

\author{
Wiwied Ekasari $\mathbb{D}^{\mathbb{D}},{ }^{1}$ Anisah Mahardiani $\mathbb{D}^{1},{ }^{1}$ Nindya T. Putri $\left(\mathbb{D},{ }^{1}\right.$ Tutik S. Wahyuni $\mathbb{D}^{1},{ }^{1}$ \\ and Heny Arwati $\mathbb{C}^{2}$ \\ ${ }^{1}$ Department of Pharmaceutical Sciences, Faculty of Pharmacy, Universitas Airlangga, Surabaya 60115, Indonesia \\ ${ }^{2}$ Department of Parasitology, Faculty of Medicine, Universitas Airlangga, Surabaya 60132, Indonesia \\ Correspondence should be addressed to Wiwied Ekasari; wiwied-e@ff.unair.ac.id
}

Received 21 November 2021; Accepted 13 January 2022; Published 15 February 2022

Academic Editor: Yoshiaki Hikasa

Copyright (c) 2022 Wiwied Ekasari et al. This is an open access article distributed under the Creative Commons Attribution License, which permits unrestricted use, distribution, and reproduction in any medium, provided the original work is properly cited.

\begin{abstract}
Currently, the presence of antimalarial drug resistance has become a major obstacle in the treatment of malaria. To overcome the problem, a series of studies are needed to find new antimalarial drugs from plants. Previously, $90 \%$ ethanolic extract of Cassia spectabilis DC (EECS) leaves have been reported to have antimalarial activity in vitro against Plasmodium falciparum and in vivo against Plasmodium berghei ANKA. The research is conducted to find out the toxicity and protective effects of EECS on the liver and kidneys of mice infected with $P$. berghei ANKA. The acute and subacute toxicity tests were carried out on healthy mice that were given EECS at a dose of $150 \mathrm{mg} / \mathrm{kg} \mathrm{BW}$. An antimalarial activity test was carried out at doses of $150 \mathrm{and} 200 \mathrm{mg} / \mathrm{kg}$ BW in P. berghei-infected mice. Regarding hepatomegaly, further plasma levels of hepatic enzyme were analyzed, as well as histopathological observation of the liver to determine the effect of the extract on liver. The kidney was observed histopathologically as well. The acute toxicity test of EECS showed that there was no mouse died at the highest dose, indicating safe for the mice. The subacute toxicity based on the histology data showed no significant difference in the liver and kidney of mice between the tested group and the healthy group. The histological and enzymatic effect of EECS in mice infected with $P$. berghei showed the histological and enzymatic effect that improved liver function and the histopathological effect on kidneys with the highest activity at a dose of $200 \mathrm{mg} / \mathrm{kg}$ BW compared with the negative control. The results showed the EECS was not toxic in mice and repaired the liver and kidney functions of $P$. berghei ANKA-infected mice, indicating a good candidate for antimalarial drug development.
\end{abstract}

\section{Introduction}

Until this day, the problem of Plasmodium parasitic resistance towards existing antimalarial drugs is still a major problem for the eradication of malaria [1-3]. Therefore, research on the discovery of new sources of antimalarial drugs, one of which is from medicinal plants, continues to be done [4]. In vivo and in vitro models have long been used in antimalarial testing. In the latter half of the 20th century, Plasmodium berghei or Plasmodium yoelii was used to infect rodents. Meanwhile, $P$. berghei became the most commonly used species for study at the liver stage, particularly the formation of hypnozoite to investigate malarial recurrence [5-7].

One of the traditional plants in Indonesia, Cassia spectabilis DC of the Caesalpiniaceae family, has been proved experimentally in vitro against $P$. falciparum and in treating malaria in vivo against $P$. berghei $[8,9]$, indicating that C. spectabilis DC plant is very potential to be further developed as a candidate for antimalarial drugs. Previous works reported that an in vivo test on $90 \%$ ethanolic extract of C. spectabilis DC leaf against P. berghei ANKA in BALB/c mice showed that an $\mathrm{ED}_{50}$ value was $131.5 \mathrm{mg} / \mathrm{kg} \mathrm{BW}$ [9], and it is categorized as very good antimalarial activity [10]. 
Furthermore, the extract, fractions, subfractions, and isolated compound of C. spectabilis DC have been tested in vitro for their antimalarial activities. The active compound of this plant has been successfully identified as a compound that is identical to (-)-7-hydroxycassine, and its in vitro antimalarial activity test showed a very low $\mathrm{IC}_{50}$ of $0.016 \mu \mathrm{g} / \mathrm{mL}$ [11], which is classified as a very strong antimalarial activity [12].

The research on this plant in relation to overcoming malarial drug resistance has been continued by examining the safety and effects of improving C. spectabilis DC leaf extract on the liver and kidney functions in $P$. berghei ANKA-infected mice. Research studies on the effect of medicinal plants that have antimalarial activity on the liver and kidney functions of mice infected with parasites have been widely carried out [13-16], as well as acute and subacute toxicity tests [17-20]. The liver has an important role in regulating physiological processes. This organ is involved in several vital functions such as metabolism, secretion, and storage. In addition, the liver has an important role in the detoxification and excretion of endogenous and exogenous compounds [21-24].

Malarial infection begins when sporozoites are injected by malarial parasite-infected female Anopheles mosquito bite. During blood feeding, infected female Anopheles injects the sporozoite stage of parasite $[25,26]$. After about an hour traveling in human body, sporozoites then enter the liver, attack hepatocytes, and start the asexual cycle of exoerythrocytic schizogony. Inside the liver cells, the parasites multiply asexually, until they reach mature schizont, and finally, a large number of merozoites produce and enter the bloodstream after infecting hepatocyte burst. The infected hepatocytes causing liver damage due to the rupture of infected hepatocytes and merozoites enter the bloodstream and start the erythrocytic cycle in the red blood cells [27, 28]. Damage that occurs in the liver cells can increase the enzymes that work on liver function, especially transaminase enzyme and morphological changes in the appearance of liver [29, 30], such as hepatomegaly. Hepatosplenomegaly is a common feature of malarial infection in humans [31] and mice [32] caused by chronic exposure to malarial parasites. However, no enlargement of kidney in malaria infection.

The dysfunction of the liver can be detected by hepatocellular transamination of plasma glutamic oxaloacetic transaminase (SGOT) and plasma glutamic pyruvic transaminase (SGPT) released in plasma, or by histological examination of the tissue [33]. The most common damage is the activation of apoptotic cell death or hepatocyte necrosis [34-36]. Clinically significant kidney involvement is associated with the infection by $P$. falciparum and $P$. malariae. The infection of $P$. falciparum produces acute manifestations, ranging from asymptomatic, up to urinary disorders, and mild electrolyte disturbances for acute renal failure $(\mathrm{ARF})$ or acute kidney injury (AKI) that require dialysis support [27, 37]. The cases of AKI in the complication of malaria are known to contribute to a high mortality rate, which is about $75 \%$ of cases. The histological study suggests the presence of glomerulonephritis, acute tubular necrosis, and interstitial nephritis as the key hemodynamic factor in malaria-associated AKI [38]. Generally, the degree of kidney dysfunction can be detected by the presence of adequate amounts of protein in the urine and an increase in the plasma urea, creatinine, and plasma electrolyte levels [39].

The toxicity of $90 \%$ ethanolic extract of C. spectabilis DC (EECS) leaves in BALB/c mice, followed by the enzyme examinations, may affect histopathology and liver and kidney functions post-EECS administration.

\section{Materials and Methods}

2.1. Plant Material and Preparation of EECS. The C. spectabilis DC leaves were purchased and determined in LIPI (Indonesia Research Centre), Botanical Garden, Purwodadi, East Java, Indonesia (B-160/IPH.06/KS.02/III/ 2019). The specimen was deposited as the herbarium in the Department of Pharmacognosy and Phytochemistry, Faculty of Pharmacy, Universitas Airlangga. The leaves were rinsed thoroughly with tap water to remove extraneous contaminants, dried at $45^{\circ} \mathrm{C}$, and ground into powder with a grinder. The extraction was carried out by macerating the powder plant materials $(500 \mathrm{~g}$ ) in a flask containing 2,500 $\mathrm{mL}$ of $90 \%$ ethanol (at $25-30^{\circ} \mathrm{C}$ ) for $3 \times 24$ hours. The extraction solvent was separated, filtered through filter paper, and evaporated under reduced pressure by rotary evaporation. The ethanolic extract yield of $1000 \mathrm{~g}$ dried weight of C. spectabilis DC leaf powder was $10.20 \%(w / w)$ and was used in this experiment.

2.2. Animals. Male BALB/c mice aged 6-8 weeks, weight of 25-30 g, were used in the study. All mice were obtained from Farma Veterinary Center, Directorate General of Livestock and Animal Health Ministry of Agriculture, Surabaya, East Java, Indonesia. The animals were housed under standard conditions and fed with a stock diet and water ad libitum. The approval of the study protocol was obtained from the Ethics Committee for Animal Research, Universitas Airlangga, Indonesia, Number 2.KE.181.10.2018.

2.3. Acute Toxicity Test. EECS was weighted and resuspended with $0.5 \%$ sodium carboxymethyl cellulose $(\mathrm{Na}$ $\mathrm{CMC}$ ) to obtain the desired doses. BALB/c mice were fasted for 24 hours before being fed with the extract. The animals were divided into three groups, each group containing five mice. The doses for each group were 1,250; 2,500; and $5,000 \mathrm{mg} / \mathrm{kg} \mathrm{BW}$, respectively. The general behavior of each mouse was observed continuously for one hour after each dose, intermittently every four hours, and thereafter over a period of 24 hours [40-42].

2.4. Subacute Toxicity Test. In the subacute toxicity test, mice were grouped into three groups and each group was treated with EECS at once, five times, and ten times of $150 \mathrm{mg} / \mathrm{kg}$ BW daily oral dose for 28 days; the normal control group was only given food and drink ad libitum [43]. The animals were observed for 28 days for any sign of toxicity. At the end 
of observational period, all animals were sacrificed under ether anesthesia and vital organs such as livers and kidneys were removed from all animals for gross and histopathological examinations.

2.5. Rodent's Parasite. Chloroquine sensitivity of Plasmodium berghei ANKA was obtained from the Institute of Biomolecular Eijkman, Jakarta, Indonesia, and maintained by serial passaging that was used in this study.

\subsection{Effect of EECS on the Plasma Level of SGOT and SGPT.} This experiment was a suppressive test based on Peters [44]. This suppressive test was done prior to the evaluation of the EECS on the plasma level of SGOT and SGPT. The animals were infected with $P$. berghei ANKA and divided into five groups of A, B, C, D, and E. The animals were treated shortly after infection on day 0 $\left(D_{0}\right)$ and continued daily for three days $\left(D_{1}-D_{3}\right)$. Group $\mathrm{A}$ as a negative control received $0.5 \% \mathrm{Na} C M C$ orally. Groups B and C as the treated groups were given EECS at a single oral dose of 150 and $200 \mathrm{mg} / \mathrm{kg} \mathrm{BW}$, respectively. Group D was a positive control given chloroquine at a single oral dose of $100 \mathrm{mg} / \mathrm{kg} \mathrm{BW}$. Moreover, group $\mathrm{E}$ as a healthy control was not infected with parasites and was only given food and drink ad libitum. On the fourth day $\left(D_{4}\right)$, the blood smears of each mouse were prepared and examined microscopically. Further, plasma was collected prior to the measurement of SGOT and SGPT levels.

\subsection{Effect of EECS on Histopathology of Liver and Kidney.} At the end of the observational period, all animals were sacrificed under ether anesthesia prior to the liver and kidney removal. After weighing the organs, the tissues were then fixed in $10 \%$ formaldehyde solution and further processed for hematoxylin-eosin ( $\mathrm{H} \& \mathrm{E})$ staining. The histopathological observation was performed to find out the toxicological effect of EECS on the degenerative and necrotic cells of the tissues. The damages were graded based on Gibson-Corley et al. [45].

2.8. Statistical Analysis. The data were represented as mean \pm standard deviation (SD). One-way analysis of variance (ANOVA) was used to compare the normally distributed data among the treatments, followed by post hoc multiple comparison test when a different significance was obtained. When the data were not distributed normally, the Kruskal-Wallis and the Mann-Whitney U-test were used to assess the differences among treatments.

\section{Results}

3.1. Acute Toxicity Test. No mice died were observed within 24 hours postoral administration of the extract. The behavioral observation of the mice mediated no toxicity sign effects such as paw licking, hair erection, reduction in feeding activity, and increasing respiratory rate [46, 47].
TABLE 1: Number of animals' deaths in the acute toxicity test of EECS on $\mathrm{BALB} / \mathrm{c}$ mice in 24 hours.

\begin{tabular}{lc}
\hline Doses $(\mathrm{mg} / \mathrm{kg} \mathrm{BW})$ & Number of deaths $(r)$ \\
\hline 1,250 & 0 \\
2,500 & 0 \\
5,000 & 0 \\
\hline
\end{tabular}

Based on the number of animals' death from the three doses of extract (see Table 1 ), yielding $r$ values were 0,0 , and 0 , assuming there was no animal died at the highest dose (5,000 mg/kg BW).

3.2. Subacute Toxicity Test. The gross examination of the liver showed hepatomegaly, but there was no enlargement of the kidneys. The size and cell morphology of liver and kidney in both the treated and control groups were similar among the groups (see Figure 1). The results of histopathological changes in the liver and kidney tissues are summarized in Table 2. Statistically, there was no significant difference $(p>0.05)$ and histopathological changes were observed in the liver and kidney tissues of the test groups when compared to the control groups.

3.3. Effect of EECS on SGOT and SGPT. The effect of EECS on biochemical parameters showed that the EECS intake induced a significant increase in plasma levels of SGOT at the dose of $150 \mathrm{mg} / \mathrm{kg} \mathrm{BW}$ and was out of the normal range. The normal range of SGOT was 59-247 U/L and SGPT in mouse was 28-132 U/L [48], while the plasma level of SGPT was still in the normal range. At a dose of $200 \mathrm{mg} / \mathrm{kg}$ BW, the plasma levels of either SGOT or SGPT were in the normal range. There was a very sharp increase in the plasma levels of SGOT and SGPT in the negative control group, indicating liver damage (see Table 3).

The observations on the morphology of liver and kidneys of mice showed the enlargement of the liver (hepatomegaly) and showed differences in color, size, and texture in the liver. The morphology of kidneys showed no enlargement and was similar either in color, size, or texture among groups. Due to these reasons, the biochemistry examination of the kidney was not performed. Physically, there was an improvement in the liver of mice treated with $150 \mathrm{mg} / \mathrm{kg}$ BW of extract when compared to the control, although it was not as good as in mice treated with $200 \mathrm{mg} / \mathrm{kg} \mathrm{BW}$ of extract. In addition, the appearance of the liver treated with $200 \mathrm{mg} / \mathrm{kg} \mathrm{BW}$ extract was almost as same as the condition of experimental mouse liver treated with chloroquine and the healthy control group, where brownish-red and smooth texture of surface has appeared.

The results of histopathological changes in the liver and kidney tissues are summarized in Table 4 . There were no significant histopathological changes observed in the liver and kidney tissues of the mice when compared to the control. The histopathological changes in liver and kidney are shown in Figures 2 and 3. 


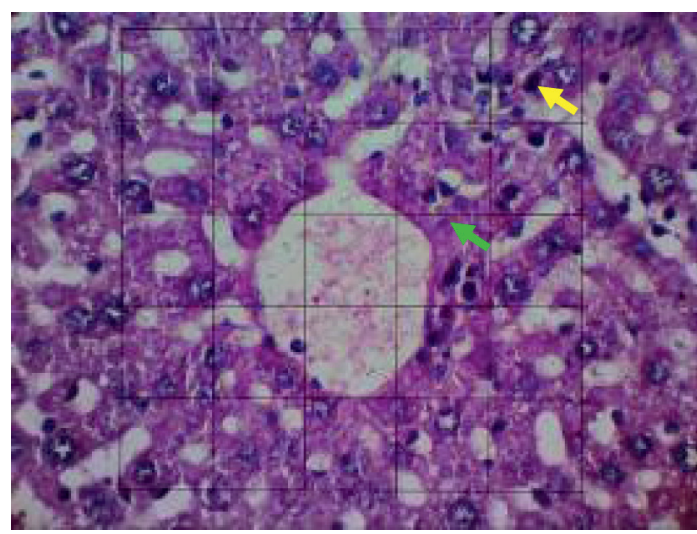

(a)

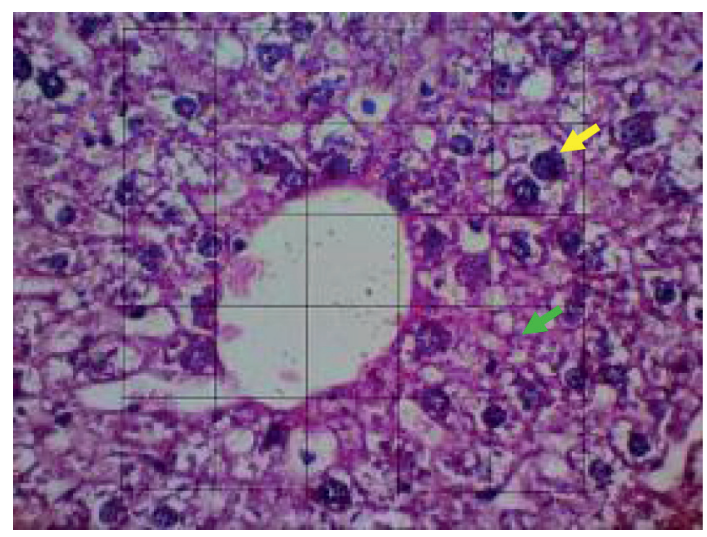

(c)

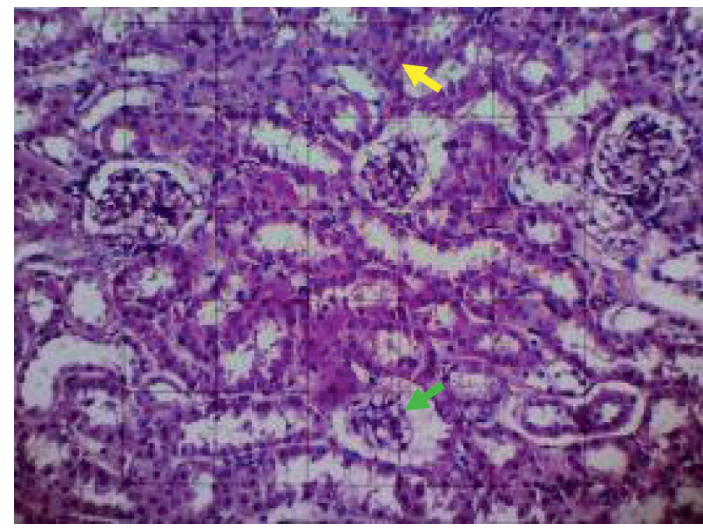

(e)

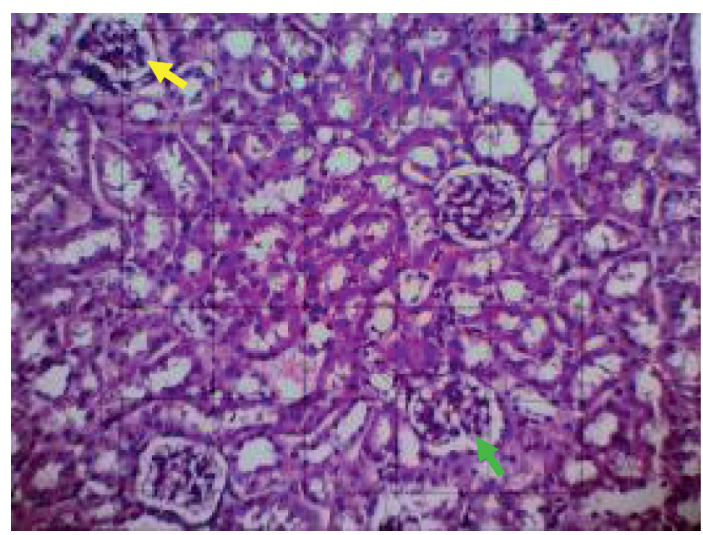

(g)

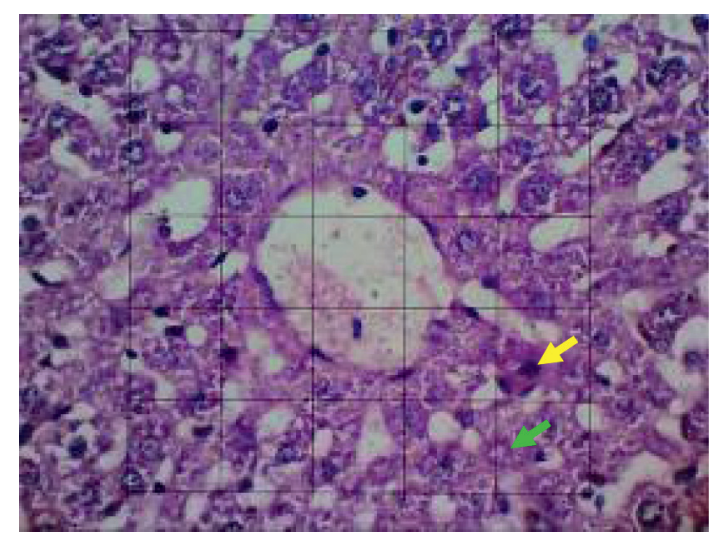

(b)

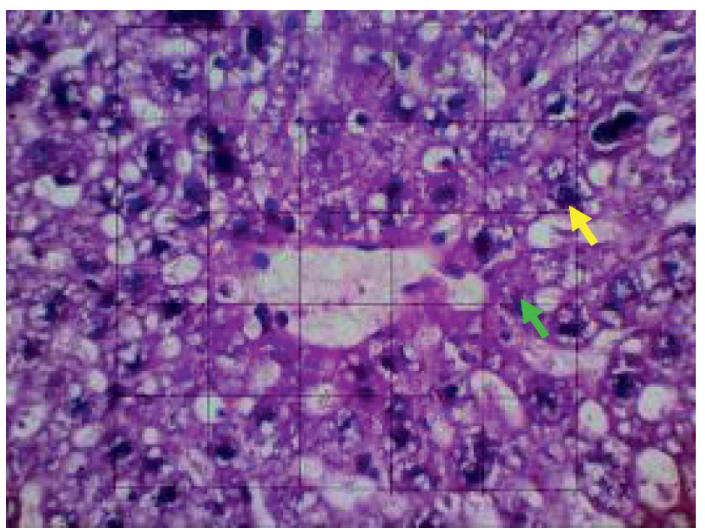

(d)

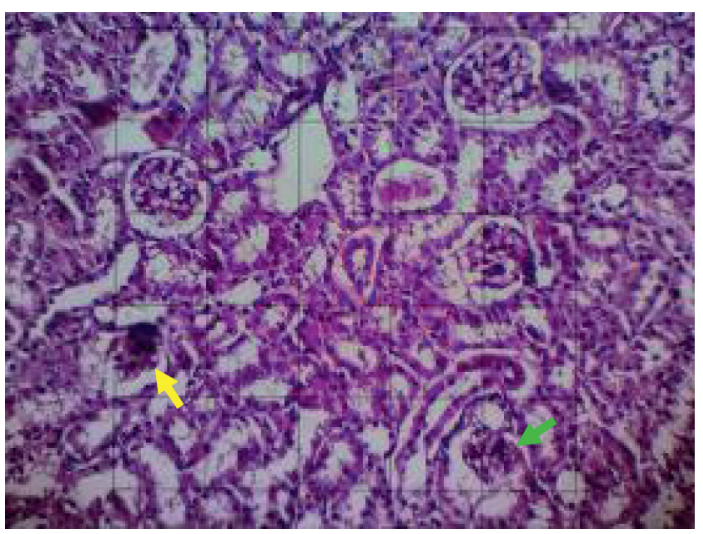

(f)

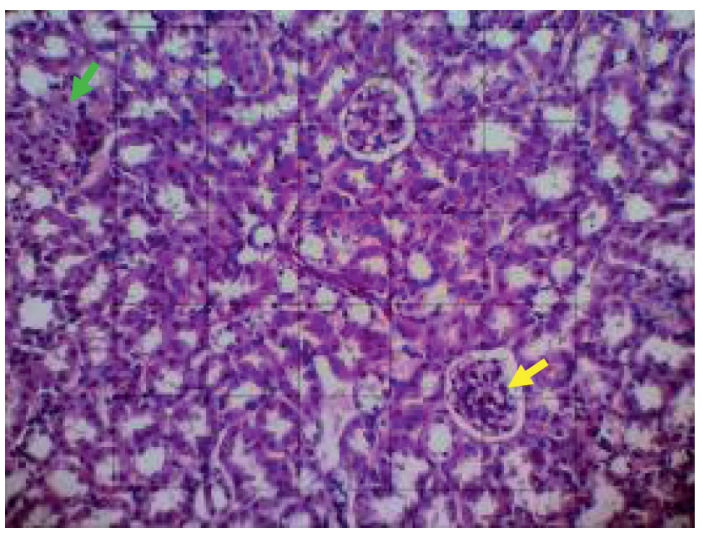

(h)

Figure 1: Histological section of the liver ( $\mathrm{a}-\mathrm{d})$ and kidney $(\mathrm{e}-\mathrm{h})$ of mice (section stained with $\mathrm{H} \& \mathrm{E}, \times 400)$. Green arrow: degenerative cell, yellow arrow: necrotic cell. (a and e) Single dose. (b and f) Five times of dose. (c and g) Ten times of dose. (d and h) Normal control groups. 
TABLE 2: Lesion scores of liver and kidney of BALB/c mice in subacute oral toxicity of EECS.

\begin{tabular}{lcccccc}
\hline \multirow{2}{*}{ Organ } & & \multicolumn{2}{c}{ Groups } & \\
& Mean score of lesions & EECS & EECS & EECS & Normal control & Asymptotic significance $(p<0.05)$ \\
& & $1 \times 150 \mathrm{mg} / \mathrm{kg}$ & $5 \times 150 \mathrm{mg} / \mathrm{kg}$ & $10 \times 150 \mathrm{mg} / \mathrm{kg}$ & & \\
\hline \multirow{4}{*}{ Liver } & Necrosis & $2.34 \pm 0.10^{\mathrm{a}}$ & $2.29 \pm 0.30^{\mathrm{a}}$ & $2.03 \pm 0.92^{\mathrm{a}}$ & $2.37 \pm 0.34^{\mathrm{a}}$ & 0.838 \\
& Degeneration & $2.20 \pm 0.16^{\mathrm{a}}$ & $2.43 \pm 0.21^{\mathrm{a}, \mathrm{b}}$ & $2.77 \pm 0.60^{\mathrm{b}, \mathrm{c}}$ & $2.26 \pm 0.25^{\mathrm{a}}$ & $0.029^{*}$ \\
& Mean score & $2.27 \pm 0.13$ & $2.36 \pm 0.25$ & $2.40 \pm 0.76$ & $2.31 \pm 0.29$ & 0.433 \\
Kidney & Necrosis & $1.94 \pm 0.32^{\mathrm{a}}$ & $1.09 \pm 0.60^{\mathrm{b}}$ & $1.54 \pm 0.63^{\mathrm{a}, \mathrm{b}}$ & $1.60 \pm 0.48^{\mathrm{a}, \mathrm{b}}$ & 0.060 \\
& Degeneration & $1.14 \pm 0.49^{\mathrm{a}}$ & $1.74 \pm 0.19^{\mathrm{b}}$ & $1.93 \pm 0.71^{\mathrm{a}, \mathrm{b}}$ & $1.86 \pm 0.46^{\mathrm{b}, \mathrm{c}}$ & 0.065 \\
& Mean score & $1.16 \pm 0.40$ & $1.41 \pm 0.39$ & $1.73 \pm 0.67$ & $1.73 \pm 0.47$ & 0.062 \\
\hline
\end{tabular}

Data are expressed as mean \pm standard deviation $(n=7)$. The superscript $\left({ }^{*}\right)$ denotes that the values were significantly different from control $(p<0.05$; Kruskal-Wallis test for global comparison of organ lesions among groups). The superscripts (a, b, c) indicate that the values in the same row with different superscript letters were significantly different ( $p<0.05$; Mann-Whitney test). EECS: 90\% ethanolic leaf extract of Cassia spectabilis DC.

TABLE 3: Differences in plasma level of SGOT and SGPT of $P$. berghei ANKA-infected mice treated with EECS compared with the control groups.

\begin{tabular}{|c|c|c|c|c|c|}
\hline \multirow{2}{*}{ Groups } & \multicolumn{2}{|c|}{ Parasitemia (\%) } & \multirow{2}{*}{ Suppression (\%) } & \multirow{2}{*}{ SGOT (U/L) } & \multirow{2}{*}{ SGPT (U/L) } \\
\hline & $D_{0}$ & $D_{4}$ & & & \\
\hline Negative control & $1.24 \pm 0.69$ & $14.42 \pm 7.86$ & - & $658.75 \pm 99.52$ & $167.75 \pm 32.37$ \\
\hline EECS $150 \mathrm{mg} / \mathrm{kg}$ & $2.13 \pm 1.19$ & $8.77 \pm 4.42$ & 51.85 & $384.75 \pm 73.98$ & $75.75 \pm 35.52$ \\
\hline EECS $200 \mathrm{mg} / \mathrm{kg}$ & $0.98 \pm 0.64$ & $9.42 \pm 3.27$ & 58.93 & $216.00 \pm 48.80$ & $42.00 \pm 4.50$ \\
\hline Chloroquine & $2.30 \pm 1.44$ & $0.14 \pm 0.28$ & 100.00 & $175.50 \pm 45.59$ & $41.25 \pm 5.60$ \\
\hline Healthy control & - & - & - & $162.50 \pm 59.18$ & $97.25 \pm 44.70$ \\
\hline
\end{tabular}

Data are expressed as mean \pm standard deviation $(n=4)$. No significant difference between the groups $(p>0.05$; one-way ANOVA followed by Tukey's multiple comparison test). $D_{0}$ : day before the treatment; $D_{4}$ : fourth day after treatment; SGOT: plasma glutamic oxaloacetic transaminase; SGPT: plasma glutamic pyruvic transaminase; EECS: 90\% ethanolic leaf extract of Cassia spectabilis DC.

TABle 4: Lesion scores of liver and kidney of P. berghei ANKA-infected mice treated with EECS.

\begin{tabular}{|c|c|c|c|c|c|c|}
\hline \multirow[b]{2}{*}{ Organ } & \multirow[b]{2}{*}{ Mean scores of lesions } & \multicolumn{5}{|c|}{ Groups } \\
\hline & & Negative control & $\begin{array}{c}\text { EECS } \\
150 \mathrm{mg} / \mathrm{kg}\end{array}$ & $\begin{array}{c}\text { EECS } \\
200 \mathrm{mg} / \mathrm{kg}\end{array}$ & Chloroquine & Healthy control \\
\hline \multirow{3}{*}{ Liver } & Necrosis & $1.30 \pm 0.26^{\mathrm{a}}$ & $0.75 \pm 0.34^{\mathrm{a}, \mathrm{b}}$ & $0.60 \pm 0.16^{\mathrm{b}}$ & $0.65 \pm 0.10^{\mathrm{b}}$ & $0.50 \pm 0.12^{\mathrm{b}}$ \\
\hline & Degeneration & $2.45 \pm 0.38^{\mathrm{a}}$ & $1.45 \pm 0.19^{\mathrm{b}}$ & $1.10 \pm 0.35^{\mathrm{b}}$ & $1.20 \pm 0.28^{\mathrm{b}, \mathrm{c}}$ & $0.65 \pm 0.10^{c}$ \\
\hline & Mean score & $1.87 \pm 0.32$ & $1.10 \pm 0.26$ & $0.85 \pm 0.25$ & $0.92 \pm 0.19$ & $0.57 \pm 0.11$ \\
\hline \multirow{3}{*}{ Kidney } & Necrosis & $1.75 \pm 0.50^{\mathrm{a}}$ & $1.55 \pm 0.41^{\mathrm{a}, \mathrm{b}}$ & $1.65 \pm 0.19^{\mathrm{a}}$ & $1.40 \pm 0.28^{\mathrm{b}}$ & $1.20 \pm 0.36^{\mathrm{c}}$ \\
\hline & Degeneration & $1.30 \pm 0.74^{\mathrm{a}, \mathrm{b}}$ & $1.20 \pm 0.52^{\mathrm{a}, \mathrm{b}}$ & $1.20 \pm 0.16^{\mathrm{a}, \mathrm{b}}$ & $1.10 \pm 0.26^{\mathrm{a}}$ & $1.45 \pm 0.68^{\mathrm{b}}$ \\
\hline & Mean score & $1.52 \pm 0.62$ & $1.37 \pm 0.46$ & $1.42 \pm 0.17$ & $1.25 \pm 0.27$ & $1.32 \pm 0.52$ \\
\hline
\end{tabular}

Data are expressed as mean \pm standard deviation $(n=7)$. No significant difference between the groups ( $p>0.05 ;$ Kruskal-Wallis test). The superscripts (a, b, c) indicate that the values in the same row with different superscript letters were significantly different ( $p<0.05$; Mann-Whitney test). EECS: $90 \%$ ethanolic leaf extract of Cassia spectabilis DC.

\section{Discussion}

Currently, the optimal use of available drugs and the development of a new approach to antimalarial chemotherapy are still needed. With serious consideration for safety issues, researches on phytochemistry, pharmacology, and biochemistry in medicinal plants traditionally used as antimalarial are urgently needed [49]. The plants that show good antimalarial activities that have been recorded until today come from 1,277 plants from 160 plant families [50, 51].

The acute toxicity test of the EECS showed that the EECS is not toxic to the BALB/c mice up to $5,000 \mathrm{mg} / \mathrm{kg} \mathrm{BW}$ of dose, since there was no mouse died due to this highest dose of EECS. Following this test, the subacute toxicity test showed that there was no abnormality in mouse mobile activities and in water and food consumption.
In addition, the subacute toxicity test was based on the liver and kidney histopathology results (see Figure 1). The data obtained based on microscopic observations were analyzed statistically in the form using the Kruskal-Wallis statistical test to determine the differences in all population groups. Based on the results of the Kruskal-Wallis test, which evaluated liver necrosis damage, it was known that there were no significant differences between the groups. This could be seen from the value of $p>0.05$. Then, the Mann-Whitney statistical test was also performed to determine the location of differences between the groups. Based on the results of the Mann-Whitney test on the level of liver necrosis damage, it was known that there were no significant differences between the values of $p>0.05$. Likewise in liver degeneration damage, it could be seen that the four treatment groups showed no 


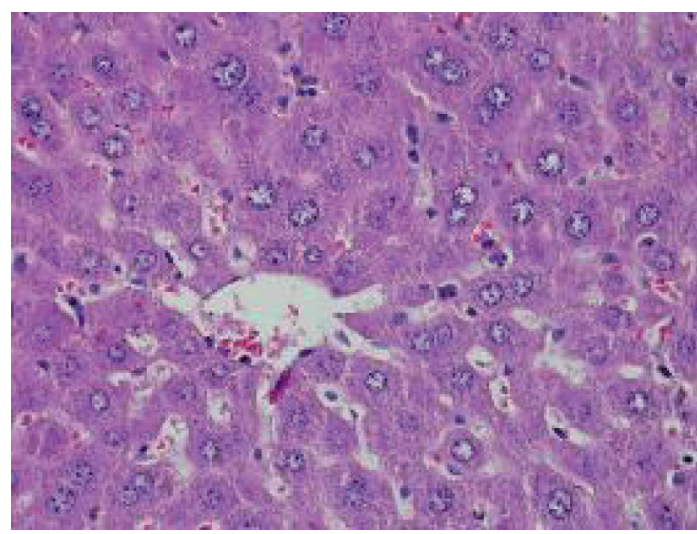

(a)

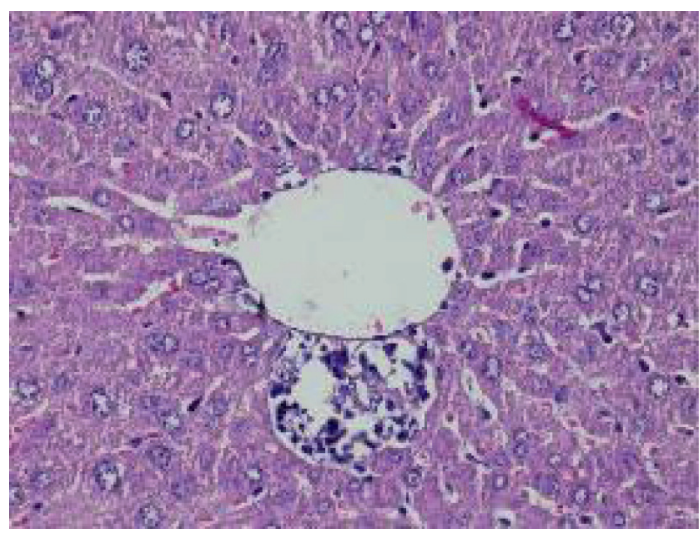

(c)

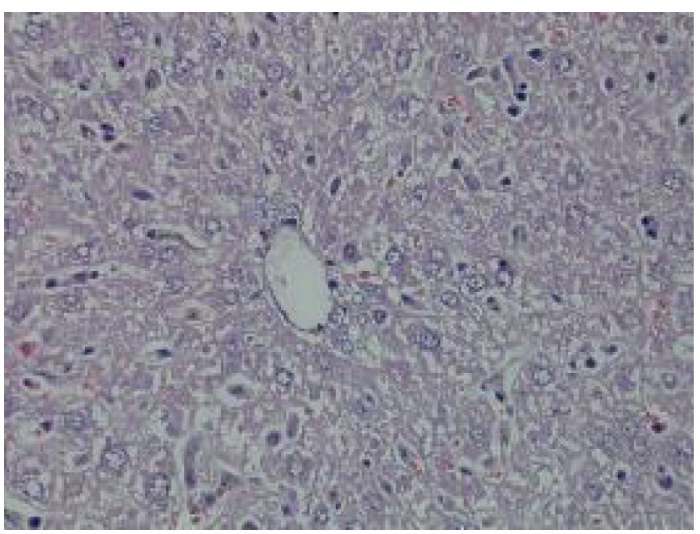

(b)

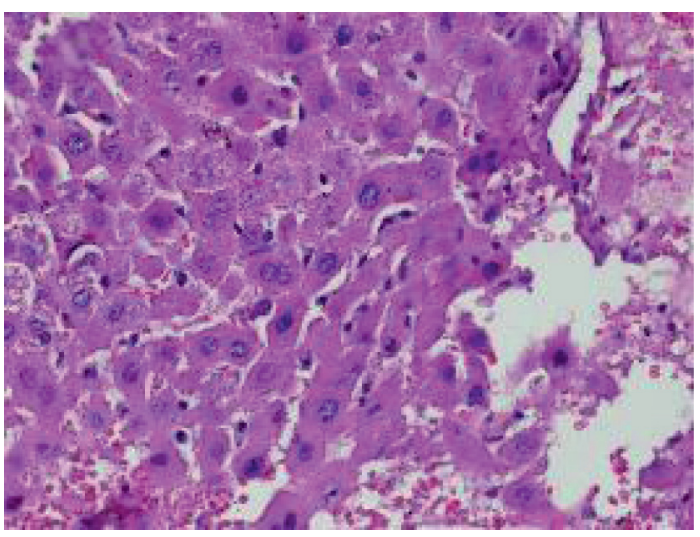

(d)

Figure 2: Pathological lesions around the central vein of experimental mouse liver (section stained with H\&E, $\times 400$ ). (a) Normal hepatocyte cells around the central vein. (b) Degenerative nuclear hepatocyte. (c) Inflammatory cell infiltration. (d) Necrotic hepatocyte.

significant differences because there were no significant differences (not toxic to the liver).

The suppressive test of the EECS in this current research was performed to find out the effect of EECS on the function of the liver based on the plasma level of SGOT and SGPT. The doses of EECS used in this test were based on the previous suppressive test [9]. Furthermore, the plasma level of SGOT and SGPT in EECS-treated infected mice was maintained in the normal range compared with the controls and based on the reference of normal BALB/c mice [52], especially at the dose of $200 \mathrm{mg} / \mathrm{kg} \mathrm{BW}$. The statistical analysis showed no significant difference $(p<0.05)$ in plasma level of SGOT and SGPT when compared with the healthy control group. These results indicated that the EECS was effective in reducing plasma levels of SGOT and SGPT to the normal levels. The excessive hepatic enzymes were released by the injured hepatocytes due to malarial infection [53]. In this study, the necrosis and degraded cells in the liver were repaired by the administration of EECS followed by the reduction in plasma level of SGOT and SGPT. These results indicated a very good liver functional improvement due to the EECS administration.

Apart from blood analysis, the histopathological analysis provides supportive evidence for biochemical and hematological assessment [41]. Histopathological examination is the standard for evaluating treatment for pathological changes in tissues and organs [54]. Histopathological assessment of the effect of EECS on the liver samples treated in this study showed both necrosis and degeneration of hepatocytes and kidney cells (see Table 4). It is likely that these changes may reflect beneficial cellular adaptations of the extract to host tissues.

Based on the results, all doses showed significant differences in kidney lesion scores when compared to the controls (see Table 4). There was a significant difference between chloroquine and the healthy group in necrotic and degenerative cells of kidney. This significant difference shows that chloroquine provides a therapeutic effect on kidney repair in $P$. berghei-infected mice.

In the absence of significant differences between the treated group and chloroquine (see Table 4), it can be concluded that the therapeutic effect is not too different from being used as an alternative to antimalaria, which can reduce kidney damage. Furthermore, a dose of $200 \mathrm{mg} / \mathrm{kg}$ BW showed better liver repair activity than a dose of $150 \mathrm{mg} / \mathrm{kg}$ BW because there was no significant lesion score in the dose of $150 \mathrm{mg} / \mathrm{kg}$ BW compared with the negative control. 


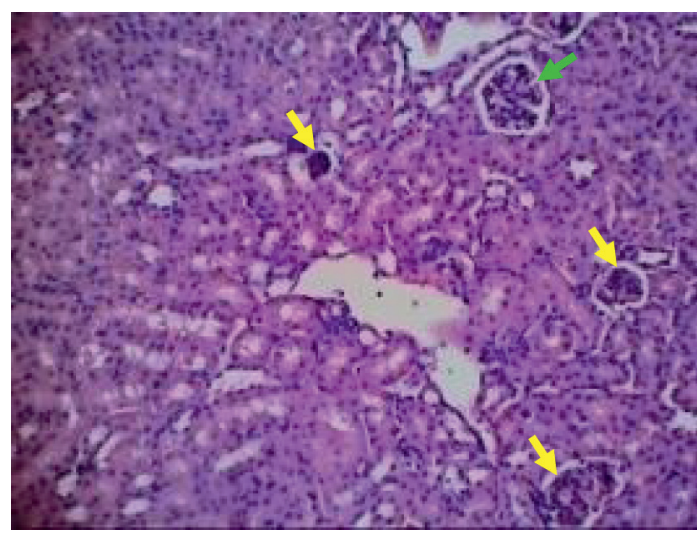

(a)

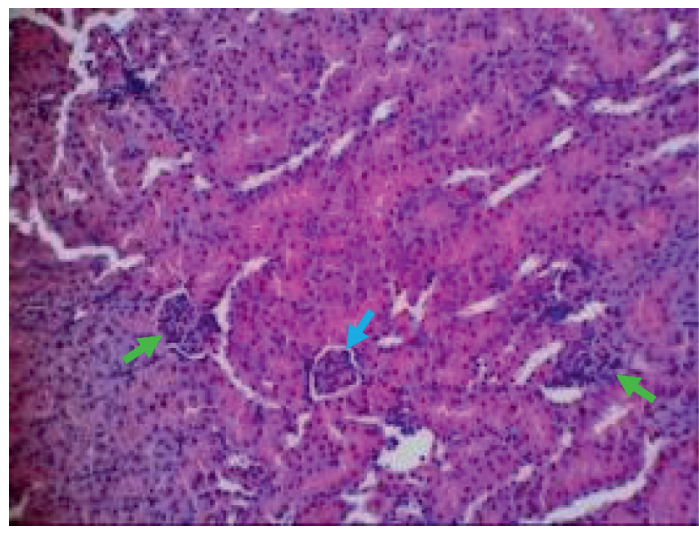

(c)

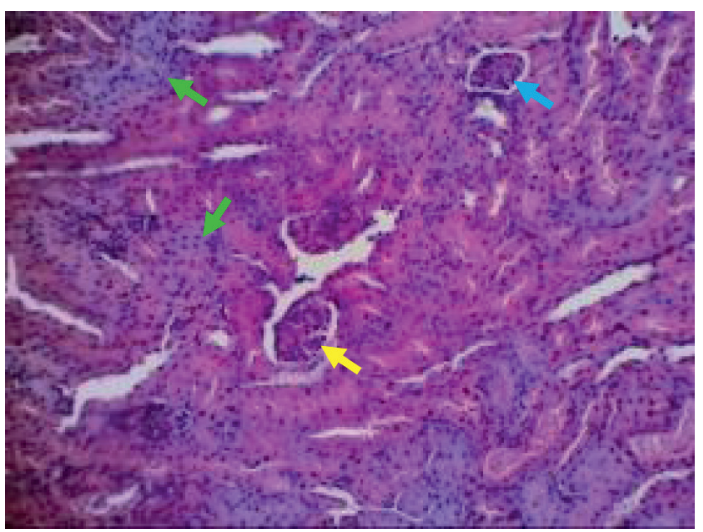

(b)

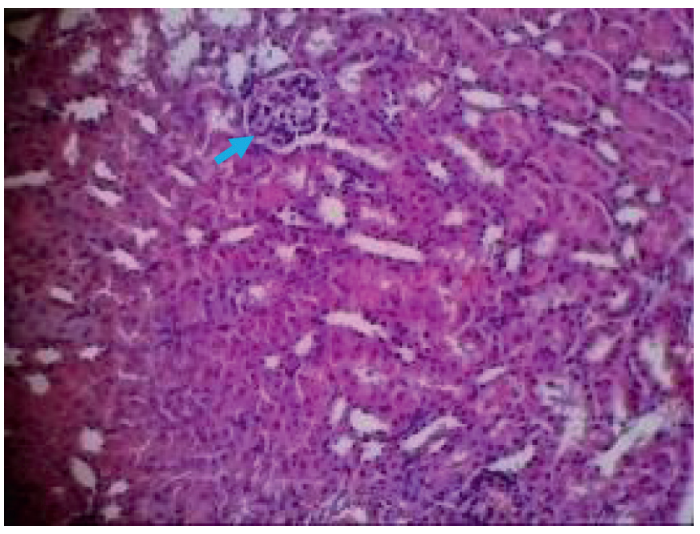

(d)

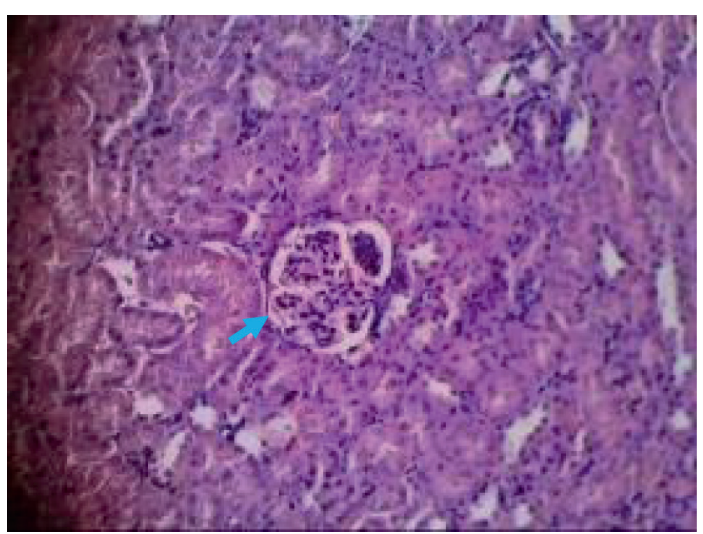

(e)

FIGURE 3: Histopathological appearances of kidney (section stained with H\&E, $\times 400$ ). Green arrow: degenerative cell, yellow arrow: necrotic cell, blue arrow: normal cell. (a) Negative control group. (b) $150 \mathrm{mg} / \mathrm{kg} \mathrm{BW}$ of extract. (c) $200 \mathrm{mg} / \mathrm{kg}$ BW of extract. (d) Chloroquine. (e) Healthy control group.

The EECS has been proved to be not toxic in mice and was able to repair the liver and kidney functions in mice infected with $P$. berghei ANKA. The ability of EECS in heme detoxification caused the parasite clearance [11] followed by further repairing of tissue in the main organ affected by the malarial infection such as liver and kidney as well as the plasma level of hepatic enzyme. 


\section{Conclusion}

The EECS was not toxic in mice and repaired the liver and kidney functions of $P$. berghei ANKA-infected mice similarly to chloroquine, indicating a good candidate for antimalarial drug development.

\section{Data Availability}

The data used to support the findings of this study are available from the corresponding author upon request.

\section{Conflicts of Interest}

The authors declare that there are no conflicts of interest regarding the publication of this study.

\section{Acknowledgments}

This research was supported by the Ministry of Education, Culture, Research and High Education of the Republic of Indonesia.

\section{References}

[1] M. Tanner, B. Greenwood, C. J. Whitty et al., "Malaria eradication and elimination: views on how to translate a vision into reality," BMC Medicine, vol. 13, no. 167, p. 167 , 2015.

[2] B. Hanboonkunupakarn and N. J. White, "The threat of antimalarial drug resistance," Tropical Disease, Travel Medicine and Vaccines, vol. 210 pages, 2016.

[3] D. Menard and A. Dondorp, "Antimalarial drug resistance: a threat to malaria elimination," Cold Spring Harbor Perspectives in Medicine, vol. 7, no. 7, Article ID a025619, 2017.

[4] H. Ginsburg and E. Deharo, "A call for using natural compounds in the development of new antimalarial treatments-an introduction," Malaria Journal, vol. 10, no. S1, 2011.

[5] A. Rodriguez-acosta, H. J. Finol, M. Pulido-Mendez et al., "Liver ultrastructural pathology in mice infected with Plasmodium berghei," Journal of Submicroscopic Cytology and Pathology, vol. 30, no. 2, pp. 299-307, 1998.

[6] E. Aidoo, F. K. Addai, J. Ahenkorah, B. Hottor, K. A. Bugyei, and B. A. Gyan, "Natural cocoa ingestion reduced liver damage in mice infected with Plasmodium berghei (NK65)," Research and Reports in Tropical Medicine, vol. 3, pp. 107-116, 2012.

[7] R. Raphemot, D. Posfai, and E. R. Derbyshire, "Current therapies and future possibilities for drug development against liver-stage malaria," Journal of Clinical Investigation, vol. 126, no. 6, pp. 2013-2020, 2016.

[8] W. Ekasari, T. S. Wahyuni, and R. A. S. Yudistira, "Potensi antimalaria dan pemeriksaan mikroskopik-fitokimia daun beberapa tanaman genus Cassia," Jurnal Farmasi dan Ilmu Kefarmasian Indonesia, vol. 2, no. 2, pp. 48-52, 2015.

[9] W. Ekasari, T. S. Wahyuni, H. Arwaty, and N. T. Putri, "Determination of effective dose of antimalarial from Cassia spectabilis leaf ethanol extract in Plasmodium berghei-infected mice," African Journal of Infectious Diseases, vol. 12, no. S1, pp. 110-115, 2018.

[10] V. Muñoz, M. Sauvain, G. Bourdy et al., "A search for natural bioactive compounds in bolivia through a multidisciplinary approach: part I. evaluation of the antimalarial activity of plants used by the chacobo Indians," Journal of Ethnopharmacology, vol. 69, no. 2, pp. 127-137, 2000.

[11] W. Ekasari, D. R. Basuki, H. Arwati, and T. S. Wahyuni, "Antiplasmodial activity of ethanolic extract of Cassia spectabilis DC leaf and its inhibition effect in heme detoxification," BMC Complementary Medicine and Therapies, vol. 21, no. 1, p. 71, 2021.

[12] P. Rasoanaivo, E. Deharo, S. Ratsimamanga-Urverg, and F. Frappier, "Guidelines for the nonclinical evaluation of the efficacy of traditional antimalarials," in Traditional Medicinal Plants and Malaria, pp. 256-268, CRC Press, Boca Raton, FL, USA, 2004.

[13] D. Jebasingh, D. D. Jackson, S. Venkataraman, and B. S. Emerald, "Physiochemical and toxicological studies of the medicinal plant Cyperus rotundus L (cyperaceae)," International Journal of Applied Research in Natural Products, vol. 5, no. 4, pp. 1-8, 2012.

[14] A. Rajan, U. Bagai, and S. Chandel, "Effect of artesunate based combination therapy with homeopathic medicine China on liver and kidney of Plasmodium berghei infected mice," Journal of Parasitic Diseases: Official Organ of the Indian Society for Parasitology, vol. 37, no. 1, pp. 62-67, 2013.

[15] L. Kunlawong, N. Ponwiang, U. Jaihan, S. Srichairatanakool, C. Uthaipibull, and V. Somsak, "Anti-hemolytic effects of green and black tea aqueous extracts on Plasmodium bergheiinfected mice," Advanced Natural Products, vol. 1, pp. 1-6, 2014.

[16] S. Kalia, U. Bagai, and V. Gorki, "Effect of Albizia lebbeck on liver and kidney function of Plasmodium berghei infected mice," International Journal of Pharma Sciences and Research, vol. 6, no. 3, pp. 575-581, 2015.

[17] L. E. Kuatsienu, C. Ansah, and M. B. Adinortey, “Toxicological evaluation and protective effect of ethanolic leaf extract of Launaea taraxacifolia on gentamicin induced rat kidney injury," Asian Pacific Journal of Tropical Biomedicine, vol. 7, no. 7, pp. 640-646, 2017.

[18] S. A. Tadesse and Z. B. Wubneh, "Antimalarial activity of syzygium guineense during early and established plasmodium infection in rodent models," BMC Complementary and Alternative Medicine, vol. 17, no. 1, p. 21, 2017.

[19] A. L. M. Kognou, A. D. Tchamgoue, L. R. Y. Tchokouaha et al., "Acute and sub-chronic toxicity studies of Dichaetanthera africana (hook. F.) jacq. fel. (melastomataceae) stem bark ethanol extract," Journal of Applied Pharmaceutical Science, vol. 8 , no. 6 , pp. $147-155,2018$.

[20] P. Chaniad, T. Techarang, A. Phuwajaroanpong, and C. Punsawad, "Antimalarial activity and toxicological assessment of Betula alnoides extract against Plasmodium berghei infections in mice," Evidence-Based Complementary and Alternative Medicine, vol. 2019, Article ID 2324679, 8 pages, 2019.

[21] X. Gu and J. E. Manautou, "Molecular mechanisms underlying chemical liver injury," Expert Reviews in Molecular Medicine, vol. 14, no. e4, p. e4, 2012.

[22] J. Chiang, "Liver physiology: metabolism and detoxification," in Pathophysiology of Human Diseases, pp. 1770-1782, Elsevier, San Diego, CA, USA, 2014.

[23] R. Chatterjee and A. Mitra, "An overview of effective therapies and recent advances in biomarkers for chronic liver diseases and associated liver cancer," International Immunopharmacology, vol. 24, no. 2, pp. 335-345, 2015. 
[24] U. Ilyas, D. P. Katare, V. Aeri, and P. P. Naseef, "A review on hepatoprotective and immunomodulatory herbal plants," Pharmacognosy Reviews, vol. 10, no. 19, pp. 66-70, 2016.

[25] G. A. Josling and M. Llinás, "Sexual development in plasmodium parasites: knowing when it's time to commit," Nature Reviews Microbiology, vol. 13, no. 9, pp. 573-587, 2015.

[26] B. S. Laurent, T. A. Burton, S. Zubaidah et al., "Host attraction and biting behaviour of Anopheles mosquitoes in south Halmahera, Indonesia," Malaria Journal, vol. 16, no. 1, p. 310, 2017.

[27] R. S. Barsoum, "Malarial acute renal failure," Journal of the American Society of Nephrology, vol. 11, no. 11, pp. 2147-2154, 2000.

[28] N. Mohandas and X. An, "Malaria and human red blood cells," Medical Microbiology and Immunology, vol. 201, no. 4, pp. 593-598, 2012.

[29] National Institute of Allergy and Infectious Disease (NIAID), Understanding Malaria Fighting on Ancient Scourge, NIH Publication No. 07-7139, Department of Health and Human Services, National Institutes of Health, Bethesda, MD, USA, 2007.

[30] R. Bandyopadhyay, S. Bandyopadhyay, and A. Dutta, "Sickle cell hepatopathy," Indian Journal of Pathology \& Microbiology, vol. 51, no. 2, pp. 284-285, 2008.

[31] O. Prommano, U. Chaisri, G. D. Turner et al., "A quantitative ultrastructural study of the liver and the spleen in fatal falciparum malaria," The Southeast Asian Journal of Tropical Medicine and Public Health, vol. 36, no. 6, pp. 1359-1370, 2005.

[32] A. A. Olayode, D. A. Ofusori, T. A. B. Ogunniyi, and O. S. Sakarya, "Histomorphological studies of the liver of Plasmodium-infected albino mice after administration of aqueous leaf extract of Mangifera indica (Linn.)," Anatomy, vol. 9, no. 3, pp. 168-176, 2015.

[33] S. Biswas, N. D. Reddy, B. S. Jayashree, and C. M. Rao, "Evaluation of novel 3-hydroxyflavone analogues as HDAC inhibitors against colorectal cancer," Advances in Pharmacological Sciences, vol. 2016, Article ID 4751806, 14 pages, 2018.

[34] N. C. Nayak, S. A. Sathar, S. Mughal, S. Duttagupta, M. Mathur, and P. Chopra, "The nature and significance of liver cell vacuolation following hepatocellular injury-an analysis based on observations on rats rendered tolerant to hepatotoxic damage," Virchows Archiv, vol. 428, no. 6, pp. 353-365, 1996.

[35] M. E. Guicciardi, H. Malhi, J. L. Mott, and G. J. Gores, "Apoptosis and necrosis in the liver," Comprehensive Physiology, vol. 3, no. 2, pp. 977-1010, 2013.

[36] M. Krishna, "Patterns of necrosis in liver disease," Clinical Liver Disease, vol. 10, no. 2, pp. 53-56, 2017.

[37] R. Naqvi, E. Ahmad, F. Akhtar, A. Naqvi, and A. Rizvi, "Outcome in severe acute renal failure associated with malaria," Nephrology Dialysis Transplantation, vol. 18, no. 9, pp. 1820-1823, 2003.

[38] L. C. Koopmans, M. E. van Wolfswinkel, D. A. Hesselink et al., "Acute kidney injury in imported Plasmodium falciparum malaria," Malaria Journal, vol. 14, no. 523, p. 523, 2015.

[39] E. O. Ogbadoyi and B. Gabi, "Assessment of renal function in malaria patients in Minna, north central Nigeria," African Journal of Infectious Diseases, vol. 1, no. 1, pp. 57-64, 2007.

[40] H. A. Twaij, A. Kery, and N. K. Al-Khazraji, "Some pharmacological, toxicological and phytochemical investigations on Centaurea phyllocephala," Journal of Ethnopharmacology, vol. 9, no. 2-3, pp. 299-314, 1983.

[41] Organization for Economic Co-operation and Development (Oecd), "Test no. 423: acute oral toxicity-acute toxic class method," OECD Guidelines for the Testing of Chemicals, Section 4, OECD Publishing, Paris, France, 2002.

[42] M. Firdaus, M. Astawan, D. Muchtadi, T. Wresdiyati, S. Waspadji, and S. S. Karyono, "Acute oral toxicity of methanol extract from brown algae Sargassum echinocarpum," Jurnal Pengolahan Hasil Perikanan Indonesia, vol. 15, no. 2, pp. 148-155, 2012.

[43] P. Kupradinun, A. Tepsuwan, N. Tanthasri et al., "Toxicity testing of flowers on neem tree (Azadirachta indica A. juss)," The Thai Journal of Veterinary Medicine, vol. 40, no. 1, pp. 47-55, 2010.

[44] W. Peters, J. H. Portus, and B. L. Robinson, "The chemotherapy of rodent malaria, XXII," Annals of Tropical Medicine and Parasitology, vol. 69, no. 2, pp. 155-171, 1975.

[45] K. N. Gibson-Corley, A. K. Olivier, and D. K. Meyerholz, "Principles for valid histopathologic scoring in research," Veterinary Pathology, vol. 50, no. 6, pp. 1007-1015, 2013.

[46] F. Monji, H. Hossein Tehrani, Z. Halvaei, and S. Arbabi Bidgoli, "Acute and subchronic toxicity assessment of the hydroalcoholic extract of Stachys lavandulifolia in mice," Acta Medica Iranica, vol. 49, no. 12, pp. 769-775, 2011.

[47] K. Dondee, P. Bootprom, B. Saiphet, P. Borkaew, C. Klubsri, and V. Somsak, "Antimalarial activities of Moringa oleifera leaf extract against Plasmodium berghei ANKA infection in ICR mice," International Journal of Innovative Research in Medical Science, vol. 1, no. 5, pp. 194-201, 2016.

[48] T.-H. Chow, Y.-Y. Lin, J.-J. Hwang et al., "Therapeutic efficacy evaluation of 111in-labeled PEGylated liposomal vinorelbine in murine colon carcinoma with multimodalities of molecular imaging," Journal of Nuclear Medicine, vol. 50, no. 12, pp. 2073-2081, 2009.

[49] P. T. Reeves, C. Roesch, and M. N. Raghnaill, Drug Action And PharmacodynamicsMSD Veterinary Manual, Kenilworth, NJ, USA, 2016.

[50] M. L. Willcox and G. Bodeker, "Traditional herbal medicines for malaria," BMJ, vol. 329, no. 7475, pp. 1156-1159, 2004.

[51] K. Spelman, "“Silver bullet" drugs vs. traditional herbal remedies: perspectives on malaria," HerbalGram, vol. 84, pp. 44-55, 2009.

[52] "Charles river research models: BALB/c mouse hematology," 2019, https://www.animalab.eu/sites/\%20all/pliki/produktydopobrania/balb_c_mouse_clinical_\%20pathology_data.pdf.

[53] S. N. H. Akil, "The clinical and histopathological aspect of the liver, lung, and kidney in malaria," Qanun Medika-Medical Journal Faculty of Medicine Muhammadiyah Surabaya, vol. 3, no. 2, pp. 123-135, 2019.

[54] D. Larrey, "Epidemiology and individual susceptibility to adverse drug reactions affecting the liver," Seminars in Liver Disease, vol. 22, no. 2, pp. 145-155, 2002. 